\title{
TEKNIK RELAKSASI PROGRESIVE UNTUK MENURUNKAN TINGKAT KECEMASAN SISWA MENGHADAPI UJIAN NASIONAL BERBASIS KOMPUTER
}

\author{
Nurnaningsih \\ SMAN 1 Bojongsoang \\ Email: nurna041205@gmail.com
}

\begin{abstract}
This study aims to apply Relaxation Techniques to reduce the level of anxiety of high school students when they face the Computer-Based National Examination (UNBK). Participants in this study were students of class XII who received the highest score on the anxiety scale, meaning students with high and moderate anxiety levels. The instrument used was the DASS (Depression Anxiety Stress Scale) anxiety scale consisting of 42 statement items.

The results of the preliminary study showed $60 \%$ of students experienced high levels of anxiety, and $30 \%$ were moderate and $10 \%$ experienced low levels of anxiety. Treatment performed on students is by using Progressive Relaxation Techniques for 6 sessions. Every 2x session an evaluation of the level of anxiety is completed. Students who are categorized as experiencing severe levels of anxiety and are being treated using this progressive relaxation method, they are given the task to do also relaxation at home every day before going to sleep and wake up.

The results of the study after 6 progressive relaxation sessions, it was found that the level of anxiety of the students was reduced ie students who experienced severe anxiety levels were reduced to as much as $20 \%$, who experienced moderate levels of anxiety to be completely gone. An effective Progressive Relaxation Technique is used to reduce the level of anxiety of students who will face the National Examination
\end{abstract}

Keywords:

Relaxation, Anxiety, Exams

\begin{abstract}
Abstrak
Penelitian ini bertujuan untuk menerapkan Teknik Relaksasi untuk menurunkan tingkat kecemasan siswa SMA saat akan menghadapi Ujian Nasional Berbasis Komputer (UNBK). Partisipan dalam penelitian ini adalah para siswa kelas XII yang memperoleh skor tertinggi pada skala kecemasan, artinya para siswa yang tingkat kecemasannya tinggi dan sedang. Instrument yang digunakan yaitu skala kecemasan DASS (Depression Anxiety Stress Scale) yang terdiri dari 42 item pernyataan.

Hasil kajian pendahuluan menunjukkan $60 \%$ siswa mengalami tingkat kecemasan tinggi, dan $30 \%$ sedang dan 10 $\%$ mengalami tingkat kecemasan rendah. Treatment yang dilakukan terhadap para siswa yaitu menggunakan Teknik Relaksasi Progressive sebanyak 6 sesi. Setiap 2x sesi selesai dilakukan evaluasi perkembangan level cemasnya. Para siswa yang terkategori mengalami kecemasan tingkat berat dan sedang ditreatment menggunakan metode relaksasi progressive ini, mereka diberikan tugas untuk melakukan juga relaksasi di rumah setiap hari sebelum tidur dan bangun tidur.

Hasil penelitian setelah 6 sesi relaksasi progressive, didapatkan hasil bahwa tingkat kecemasan para siswa menjadi berkurang yaitu siswa yang mengalami tingkat kecemasan berat menjadi berkurang yaitu menjadi sebanyak $20 \%$, yang mengalami tingkat kecemasan sedang menjadi hilang sama sekali. Teknik Relaksasi Progresive efektif dilakukan untuk menurunkan tingkat kecemasan para siswa yang akan menghadapi Ujian Nasional Berbasis Komputer (UNBK)
\end{abstract}

Kata Kunci:

Relaksasi, Kecemasan, Ujian

DOI: http://dx.doi.org/10.15575/saq.v4i2.7576

Received: 2020-01-23; Accepted: 2020-01-24 ; Published: 2020-01-29 


\section{A. PENDAHULUAN}

Ujian merupakan sebuah tolak ukur apakah seseorang menerima sebuah pembelajaran dengan baik atau tidak. Sebuah sekolah melakukan serangkaian ujian bagi para siswanya yang bertujuan untuk mengevaluasi proses belajar mengajar yang selama waktu tertentu dilakukan. Ujian Nasional Berbasis Komputer merupakan sebuah ujian akhir yang dilakukan di berbagai sekolah di Indonesia saat ini yang bertujuan untuk mengukur kemampuan siswa setelah sekian tahun sekolah dan ujian ini dilakukan untuk mengukur lulus tidaknya seorang siswa melakukan pendidikan di sekolah tersebut.

Ujian Nasional Berbasis Komputer atau dikenal dengan istilah UNBK merupakan media ujian menggunakan basis computer, setelah tahun-tahun sebelumnya selalu paper base test atau ujian menggunakan kertas, saat ini dirubah menjadi base computer. Dalam hal ini sekolah dan siswa dituntut untuk bisa menguasai computer. Sekolah diharuskan untuk memberikan fasilitas computer dan internet untuk mendukung kelancaran Test. Siswa diharuskan untuk dapat mengoperasikan computer dengan baik dalam menjawab berbagai soal yang diberikan.

Ujian Nasional Berbasis Komputer pertama dilaksanakan oleh setiap sekolah yaitu mulai tahun 2014, tujuannya untuk dapat meningkatkan kualitas pendidikan karena dengan terintegrasi link di seluruh Indonesia dapat mengetahui standar hasil nilai ujian nasional seluruh Indonesia secara langsung dan secara komputerisari, selain itu juga terintegrasi langsung dengan DAPODIK dan E-raport sehingga memudahkan sekolah dalam mengolah nilai dan menginput data yang berkaitan dengan nilai dan data lainnya yang diperlukan oleh siswa.

Fungsi Ujian Nasional Berbasis Komputer ini dilakukan untuk memilimalisir terjadinya berbagai tindak kecurangan yang selama ini terjadi dalam pelaksanaan ujian Paper Base Test, dengan banyak beredarnya kunci jawaban dan hal lainnya. Dengan Ujian Berbasis computer diatur dengan 20 paket, jadi tidak ada peluang siswa dan pihak lain untuk melakukan tindak kecurangan.
Berbagai tindak kecurangan yang sudah sangat akut membuat para remaja sebagai siswa di sekolah mengalami kecemasan, hal tersebut diakibatkan karena para siswa menjadi takut tidak lulus terkalahkan oleh siswa lain yang mendapatkan bocoran soal. Setelah system ujian dirubah menjadi berbasis computer, malah tingkat kecemasan semakin naik tingkatannya, karena berbagai factor diantaranya para siswa menjadi cemas karena setiap computer berbeda soalnya dan urutannya karena terdiri dari 20 paket soal. Lalu para siswa menjadi cemas diakibatkan karena kurang mahir mempergunakan computer, terutama sekolah dan para siswa yang berasal dari daerah yang awalnya memang tidak tersedia adanya computer. Lalu hal lain yang membuat tingkat kecemasan meningkat adalah ketersediaan server dan internet yang kurang memadai membuat terhambatnya proses ujian nasional berbasis computer dikarenakan antara satu computer dengan computer lainnya berbeda, tidak sedikit yang mengalami sebuah permasalahan dimana computer tiba-tiba mengalami log out otomatis atau mati lampu yang sudah diluar kemampuan para siswa dan guru di sekolah. Proses log out otomatis tersebut membuat para siswa menjadi cemas karena harus diulang menjawab soal dari semula dan semakin membuat cemas karena katakutannya tidak lulus ujian. Hal tersebutlah yang menjadi penyebab akhirnya para siswa mengalami kecemasan yang tinggi.

Oleh karenanya diperlukan treatment untuk para siswa untuk mengatasi kecemasan siswa dalam menghadapi Ujian Nasional Berbasis Komputer tersebut salah satunya menggunakan metode relaksasi progressive (Progressive Relaxation). Tujuan penulisan penelitian ini adalah untuk melihat seberapa efektif teknik relaksasi progressive dalam menurunkan tingkat kecemasan siswa dalam menghadapi ujian Nasional Berbasis Komputer (UNBK).

\section{TEKNIK RELAKSASI PROGRESIVE}

Dapat diartikan sebagai salah satu teknik terapi perrilaku yang berfungsi untuk 
melemaskan atau mengurangi ketegangan dan kecemasan pada diri seseorang, ada juga yang menyebutkan sebagai partisipasi aktif dari otot yang mengurangi ketegangan pada otot.

Apabila dilihat dari sejarah, pengertian relaksasi begitu luas ditinjau dari sudut pandang kedokteran, psikologi klinis dan psikiatri.

Secara umum relaksasi dapat diartikan sebagai sebuah cara melakukan pelemasan baik otot dan otak, terjadi suatu keheningan total yang dirasakan oleh individu pelaku program relaksasi, dimana ia dapat melampaui fikiran alam bawah sadar dan mencapai momen kedalaman serta ketenangan jiwa secara utuh. Relaksasi dapat dilakukan apabila fisik dan psikis dalam keadaan hening dan tenang, ritme otak berubah ke titik alpha yang rileks sehingga membuat kecemasan menurun, aliran darah ke otak menurun, dan aliran darah mengalir ke kulit terasa hangat dan nyaman.

Teknik Relaksasi Progressive merupakan sebuah tehnik relaksasi yang membawa seorang individu untuk relaks sampai pada otot-ototnya. Diawali dari rileks semua otot yang ada dalam tubuh mulai dari ujung kaki sampai kepala, hal ini menyebabkan susunan syaraf otonom menjadi tampak lebih bugar dan hal ini akan berpengaruh kepada psikis yang mulai tenang dan nyaman sehingga terjadi penurunan pada reaksi emosi yang tengah bergelora dan mencapai puncak emosi.

Kegunaan melakukan teknik relaksasi progressive ini diantaranya (1) relaksasi dapat membuat seseorang individu lebih mampu mengatasi reaksi berlebihan karena kecemasan, stress dan depresi, (2) semua permaslaahan yang berhubungan dengan kecemasan seperti hipertensi, sakit kepala berlebih, insomnia dapat diobati dengan teknik relaksai progressive ini dan istirahat yang cukup, (3) dapat mengurangi tingkat kecemasan seseorang dan mengurangi kemungkinan gangguan yang diakibatkan oleh sebuah peristiwa tertentu yang terjadi, (4) meningkatkan penampilan dan performance dengan bantuan relaksasi sehingga tampil dengan lebih tenang dan percaya diri serta membuat suasana sekitar pun menjadi lebih tenang pula dan nyaman, (5) relaksasi ini dapat memberikan bantuan kepada seseorang yang memiliki penyakit dan akan melakukan sebuah tindakan operasi, sehingga jiwa keadaan tubuh dan njiwanya tenang akan membuat proses operasi lebih lancar dan mudah, (6) dapat meningkatkan hubungan interpersonal dengan orang lain, karena dengan sitSuasi yang nyaman menarik orang untuk nyaman berada dekat dengan kita dan lebih berfikir rasional.

\section{KECEMASAN REMAJA}

Para remaja yang terkenal sebagai manusia yang paling banyak rintangan dan hambatan disebabkan masuk pada periode transisi dan membutuhkan berbagai energy untuk pindah dari masa kanak-kanak yang penuh dengan kebebasan dan maklum pihak lain, ke masa dewasa yang penuh aturan dan harus menjadi contoh dalam berbagai perilaku.

Begitu ketatnya aturan sosial yang terjadi dimasyarakat, membuat para remaja mudah sekali untuk mengalami kecemasan, hal tersebut bisa diakibatkan oleh diri sendiri bahkan yang paling sering dipengaruhi oleh lingkungan sekitar yang banyak tuntutan pada hidupnya.

Pergeseran generasi milenial saat ini tampaknya tidak terlalu menuntut secara aturan sosial, akan tetapi dengan dampak perkembangan teknologi yang begitu pesat saat ini tetap saja memjadikan pengaruh besar dan berdampak kepada remaja baik positif ataupun negative.

Dunia maya menjadi tolak ukur para remaja saat ini, jika dikenal di dunia maya maka hal tersebut akan menjadikan sebuah kebahagiaan tersendiri bagi mereka. Hal inilah yang seringkali menjadi pemicu, remaja menjadi mudah untuk mengalami kecemasan yang tidak beralasan. Apabila di dunia nyata masih bisa dibicarakan dan dicari solusinya dengan face to face berdialog, di dunia maya menjadi sangat kesulitan untuk mencari solusi. Apalagi pengambilan keputusan akan sangat berpengaruh oleh masukan dari netizen. Hal tersebut menjadikan pekerjaan rumah bagi semua pihak untuk bagaimana memecahkan berbagai persoalan para remaja ditinjau dari sudut pandang sosial, psikologis, teknologi 
serta agama agar lebih komprehensif dan menyeluruh.

\section{KECEMASAN DAN UJIAN}

Ujian dalam berbagai kalangan tidak sedikit yang berpandangan negative tentangnya, dalam artian sosok ujian menjadi sebuah hal yang ditakuti oleh semua orang diberbagai kalangan yang menjalaninya.

Remaja atau dalam hal ini siswa mengalami kecemasan saat akan menghadapi ujian dan saat mengikuti ujiannya itu sendiri. Hal ini merupakan hal yang buruk bagi perkembangan psikologisnya, karena bisa jadi siswa menguasai materi dan sesungguhnya bisa menjawab sebuah pertanyakan, akan tetapi karena tertutupi rasa cemas yang berlebihan sehingga membuat hal tersebut membuat hasil akhir yang buruk yang sangat tidak diharapkan.

Hal terburuk yang dialami oleh para siswa di Ujian Nasional Berbasis Komputer ini adalah dikarenakan setiap siswa dan setiap computer satu dan lainnya tidak sama soalnya karena terdiri dari 20 paket, hal tersebut membuat para siswa tidak bisa saling mencontek satu sama lain. Selain itu juga para siswa cemas karena system computer berhubungan dengan ketersediaan program computer, ketersediaan listrik dan kemampuan para siswa dalam mengoperasikan computer. Karena tidak jarang terjadi hambatan diantaranya computer tiba-tiba log out otomatis, sehingga proses menjawab soal harus diulang, hal tersebut yang membuat siswa takut tidak lulus ujian.

\section{B. HASIL DAN PEMBAHASAN}

Seluruh siswa yang terkategori mengalami tingkat kecemasan berat dan sangat berat diberikan treatment relaksasi progresive dengan enam sesi pelaksanaan, diperoleh data pre-test sebelum pelaksanaan treatment dan post test setelah selesai pelaksanaan treatment dan pemberian tugas relaksasi di rumah masing-masing. Profil pre test dan post testnya disajikan dalam tabel 1

\begin{tabular}{|l|l|c|c|c|c|}
\hline No & Nama & $\begin{array}{c}\text { Pre- } \\
\text { Test }\end{array}$ & $\begin{array}{c}\text { Post- } \\
\text { Test }\end{array}$ & $\begin{array}{c}\text { Perbedaan } \\
\text { skor }\end{array}$ & Ket. \\
\hline 1 & AB & 44 & 25 & 19 & Menurun \\
\hline 2 & AG & 40 & 20 & 20 & Menurun \\
\hline 3 & BS & 30 & 21 & 9 & Menurun \\
\hline 4 & DS & 33 & 19 & 14 & Menurun \\
\hline 5 & GG & 29 & 18 & 11 & Menurun \\
\hline 6 & LP & 35 & 26 & 9 & Menurun \\
\hline 7 & MM & 39 & 24 & 15 & Menurun \\
\hline 8 & NR & 40 & 23 & 17 & Menurun \\
\hline 9 & NN & 34 & 22 & 12 & Menurun \\
\hline 10 & ZK & 28 & 15 & 13 & Menurun \\
\hline
\end{tabular}

Tabel 1. Skor Hasil Pre-Test dan Post Test

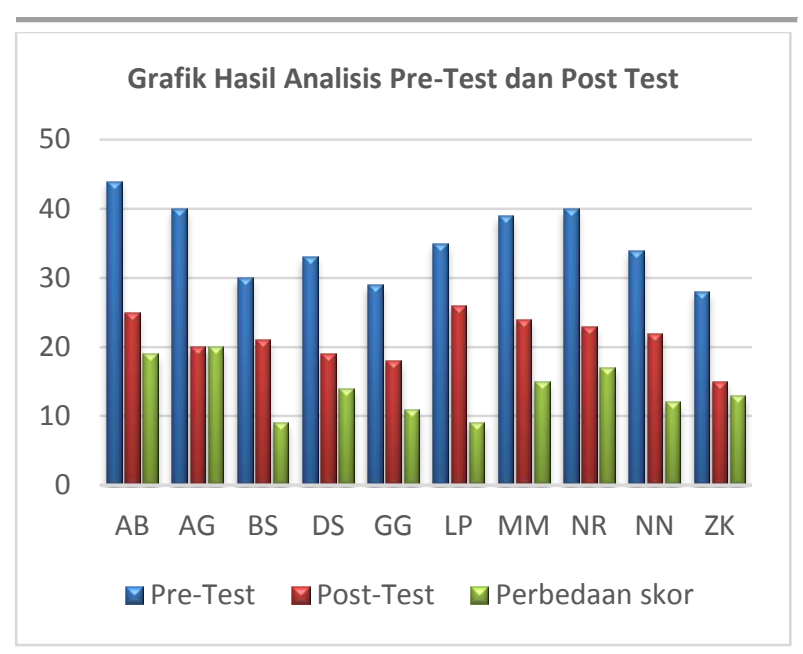

Gambar 1. Grafik Analisis Pre-Test dan Post Test.

Berdasarkan Skor hasil Pre-Test diatas didapatkan data bahwa siswa terkategori kecemasan berat dan sangat berat, setelah dilakukan treatment Relaksasi progresive sebanyak 6 sesi dan penugasan relaksasi di rumah masing-masing didapatkan skor PostTest yang cukup signifikan. Penurunan skor mulai dari angka 9 sampai 20. Hal tersebut menunjukkan bahwa terdapat perbedaan yang cukup signifikan terhadap perlakuan treatment yang dilakukan saat sebelum pemberian treatmen relaksasi progressive dan setelah pemberian treatment relaksasi progresive, meskipun setiap orang tidak sama skor nya, tergantung kekhusyuan, fokus, konsentrasi, kesungguhan ingin kecemasan berkurang dan latihan yang dilakukan di rumah masingmasing. 


\section{ANALISA PENELITIAN}

Berdasarkan hasil penelitian menunjukkan penurunan skor pada tingkat kecemasan siswa. Hal ini menunjukkan bahwa treatment yang dilakukan menggunakan teknik relaksasi progresive terhadap siswa efektif dilakukan untuk menurunkan tingkat kecemasan, apapun gejala dan penyebabnya. Hal ini sesuai dengan pendapat seorang ahli bernama Forgat ${ }^{1}$ (2016) yang menyatakan bahwa dengan melakukan relaksasi yang continue akan membantu mengendalikan berbagai hal stress, kecemasan, mengurangi rasa sakit dan membuat tubuh menjadi rileks, dengan cara melemaskan otot badan dan ketegangan otot tertentu sehingga dikendurkan dan dilemaskan menjadi lebih nyaman.

Melihat fakta diatas menunjukkan bahwa teknik relaksasi progresive yang dilakukan sangat bermanfaat untuk menurunkan tingat kecemasan, dalam hal ini kecemasan siswa yang akan menghadapi Ujian Nasional dimana hal tersebut merupakan penentu kelulusan siswa setelah selama tiga tahun belajar di Sekolah Menengah Atas, terlebih lagi sudah sejak tahun 2014 Ujian Nasional sudah dirubah menjadi Ujian Nasional Berbasis Komputer ( UNBK). Ujian Nasional paper saja mengundang berbagai kecemasan siswa dikarnakan kecemasan takut tidak lulus, apalagi berbasis komputer. Jadi selain siswa harus menguasai materi pelajaran, juga para siswa harus bisa mengoperasikan komputer lagi mulai log-in, menjawab soal, mendengarkan Voice sampai kepada Log-out yang terkadang proses tersebut menuai permasalahan, baik yang diakibatkan kendala teknis ataupun non teknis yang menghambat prosesi ujian.

Dari Grafik analisis yang ditunjukkan bahwa siswa $A G$ dan $A B$ mengalami penurunan tingkat kecemasan dengan tingkat skor penurunan paling tinggi, dapat disimpulkan teknik relaksasi ini sangat cocok untuk diterapkan kepada mereka, skor yang dihasilkan dari test DASS didapatkan skor penurunan sebanyak 19-20, ini merupakan skor yang cukup signifikan perubahannya. Setelah dilakukan wawancara dan evaluasi setiap sesi memang siswa $\mathrm{AG}$ dan $\mathrm{AB}$ selalu bersemangat ketika hendak melakukan relaksasi, meskipun kategori cemas nya mereka sangat berat, akan tetapi mereka merasa sangat memerlukan bantuan dan dengan tangan terbuka menerima bantuan. Lalu setiap sesi terapi dan saat evaluasi, siswa AG dan $\mathrm{AB}$ melakukan terapi relaksasi progresive dengan khusyu dan konsentrasi tinggi, selain itu juga mereka intens bertanya kepada konselor diluar sesi terapi tentang tata cara melakukan terapi di rumah seperti yang ditugaskan sebelumnya untuk membantu meredakan ketegangan.

Selain itu siswa BS dan LP mengalami penurunan tingkat kecemasan dengan tingkat skor penurunan paling rendah yaitu skor 9 . Hal ini bukan berarti tidak signifikan, akan tetapi memang kategori skor kecemasan di pre-test nya termasuk kategori berat dan bukan sangat berat. Selama proses treatment siswa BS dan LP menunjukkan konsentrasi penuh, hanya sesekali tampak kurang melepaskan ketegangannya, seperti masih terdapat hal-hal yang ditahan dan kurang dikhlaskan. Lalu saat ditanya apakah melakukan latihan dan proses relaksasi di rumah kedua siswa tersebut menjawab kadang-kadang, artinya tidak konsisten mereka lakukan.

\section{SIMPULAN}

Berdasarkan hasil penelitian yang diperoleh dapat disimpulkan bahwa teknik relaksasi progressive efektif untuk menurunkan tingkat kecemasan siswa menghadapi Ujian Nasional Berbasis Komputer (UNBK)

\section{DAFTAR PUSTAKA}

Dewi, Aprilia Kartika. 2015. Pelatihan Teknik Relaksasi untuk menurunkan kecemasan pada primary caregiour penderita kanker payudara. Gadjah Mada Journal of Professional Psychologis. Vol. 1. No 3. Hal. 173-192. 
Febri, Fitri. 2015. 13 Manfaat Relaksasi bagi jiwa dan kesehatan. https://dosen psikologi.com/manfaat-relaksasi-bagi jiwa. ( diakses tgl 21 November 2017)

Subandi. (2002). Psikoterapi. Pustaka Pelajar: Yogyakarta.

Suyono, Triyono, Handarini Dany $M$. 2016. Keefektifan Teknik Relaksasi untuk Menurunkan Stress Akademik siswa SMA. Jurnal Pendidikan Humaniora. Vol. 4. No. 2 Hal.115-120. 